\title{
Influence of the Thickness and Doping Concentration in p- and n-Type Poly-Si Layers on the Efficiency of a Solar Cell Based on a Carbon Fiber
}

\author{
Min-Seok Yoon, Young Bo Shim, and Young-Geun Han* \\ Department of Physics and Research Institute for Natural Sciences, Hanyang University, \\ Seoul 133-791, Korea
}

(Received December 2, 2014 : revised February 3, 2015 : accepted March 4, 2015)

\begin{abstract}
We investigated the effects of the thickness and doping concentration in $\mathrm{p}$ - and n-type poly-Si layers on the performance of a solar cell based on a carbon fiber in order to improve the energy conversion efficiency of the cell. The short-circuit current density and open-circuit voltage of the carbon fiber-based solar cell were significantly influenced by the thickness and doping concentration in the $\mathrm{p}$ - and n-type poly-Si layers. The solar cell efficiency was successfully enhanced to $\sim 10.5 \%$.
\end{abstract}

Keywords : Solar cell, Silicon solar cell, Carbon/carbon-based materials, Carbon fiber OCIS codes : (350.6050) Solar energy; (040.5350) Photovoltaic

\section{INTRODUCTION}

Miniature and flexible solar cells have been attracting considerable attention in a variety of applications such as wireless sensor networks and robots [1-5]. In comparison to rigid solar cell panels, miniature and flexible solar cells are more applicable to irregular objects or to being embedded into portable devices and clothes [1, 2]. Recently, fibershaped solar cells with a micrometer diameter have been developed [6, 7]. Since the fiber-shaped solar cells are lightweight, thin and flexible, they can be easily integrated in a curved form and are suitable for portable applications [7-10]. The first attempt to realize fiber-shaped solar cells involved dye-sensitized solar cells based on an optical fiber core electrode coated with a transparent conductive oxide (TCO) glass [8]. However, TCO glass is expensive and has a high sheet resistance, which limits its extensive application in fiber-shaped solar cells. To overcome this limitation, carbon fibers have been exploited to form the core electrode of a fiber-shaped solar cell [9]. A carbon fiber is a flexible, light-weight material with a submicrometer diameter, a good conductor with a very low resistance of $1.8 \times 10^{-5} \Omega \cdot \mathrm{m}$, and it can endure high temperatures up to $1,500^{\circ} \mathrm{C}[10]$. However, solar cells based on carbon fibers suffer from their inefficient photovoltaic structure [9]. Therefore, it is necessary to investigate the effect of the thickness and doping concentration in $\mathrm{p}$ - and n-type poly-Si layers on the solar cell efficiency.

In this study, the effects of the thickness and doping concentration in $\mathrm{p}$ - and n-type poly-Si layers on the efficiency of a solar cell based on a carbon fiber were theoretically analyzed by utilizing a finite-difference time-domain (FDTD) algorithm $[11,12]$. The solar cell efficiency $(\eta)$ based on the carbon fiber gradually increased and finally saturated with increasing thickness of the p-type poly-Si layer because of the dependence of the light harvesting efficiency $\left(\eta_{l h}\right)$ on the absorbed light intensity $\left(I_{a b s}\right)$, corresponding to the thickness of the p-type poly-Si layer $\left(t_{p}\right)$. The solar cell efficiency $(\eta)$ is directly proportional to the short circuit current density $\left(J_{s c}\right)$. The short-circuit current density $\left(J_{s c}\right)$ gradually increased and was finally saturated with increasing thickness of the p-type poly-Si layer $\left(t_{p}\right)$ because of the dependence of the light harvesting efficiency $\left(\eta_{l h}\right)$ on the absorbed light intensity $\left(I_{a b s}\right)$. However, a large thickness of the n-type poly-Si layer $\left(t_{n}\right)$ degrades the quantum efficiency $\left(\eta_{q e}\right)$ resulting in a reduction of the solar cell efficiency $(\eta)$. Since the absorption coefficient of free electrons $\left(\alpha_{f c}\right)$ in the carbon fiber-based solar cell primarily changed depending on the doping concentration in the p-type poly-Si layer $\left(N_{p}\right)$, the solar cell efficiency $(\eta)$ was enhanced by reducing the doping concentration in the p-type poly-Si layer $\left(N_{p}\right)$. Increasing the doping concentration in the n-type poly-Si layer $\left(N_{n}\right)$ enhances the open-circuit voltage $\left(V_{o c}\right)$, resulting in improvement of the solar cell efficiency $(\eta)$. By optimizing

\footnotetext{
*Corresponding author: yghan@hanyang.ac.kr

Color versions of one or more of the figures in this paper are available online.
} 
the thickness and doping concentration in the p- and n-type poly-Si layers, the solar cell efficiency $(\eta)$ based on the carbon fiber was improved up to $\sim 10.5 \%$.

\section{RESULTS AND DISCUSSION}

Figure 1 shows the (a) scheme and (b) operation principle for the solar cell based on the carbon fiber. The carbon fiber in the center of the solar cell simultaneously serves as a mechanical backbone and as electrode 1 . Photovoltaic conversion in the $\mathrm{p}$ - and n-type poly-Si layers must be achieved. While the solar cell based on the carbon fiber is illuminated by sunlight, the p- and n-type poly-Si layers will absorb photons whose energies are equal to the amount of the energy bandgap of the Si layer, and electron-hole pairs will be produced. As the electron-hole pairs reach the depletion region, the electron-hole pairs will be separated by the internal electric field induced in the junction between the p-type and n-type poly-Si layers. The electrons and holes drift toward the n-type and p-type poly-Si layers, respectively, due to the internal electric field. In Fig. 1(b), the electrons and holes in the metastable state are generally moved for the electron lifetime before their recombination. Since the recombination of the electron with the hole undesirably induces a short-circuit current density loss, the path length of the electron-hole pairs should be minimized to reduce the loss. This means that a large fraction of photogenerated electron-hole pairs should be created within the depletion region. Since over $50 \%$ of the sunlight incident on silicon is absorbed within 3 um from its surface, the thickness of the n-type poly-Si layer $(<1 \mu \mathrm{m})$ should be

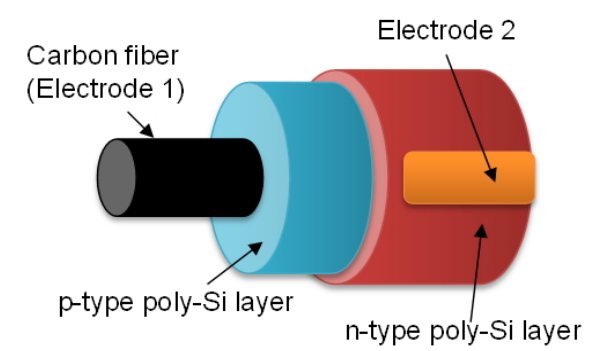

(a)

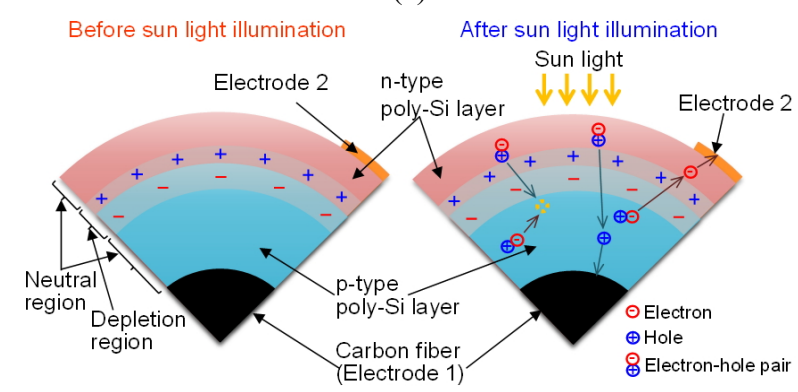

(b)

FIG. 1. (a) Structure and (b) operation principle of the solar cell based on a carbon fiber. much thinner than that of the p-type poly-Si layer $(>10 \mu \mathrm{m})$. After drifting into the p-type poly-Si layer, the holes will be collected at electrode 1 . After transport in the n-type poly-Si layer, the electrons will be gathered at electrode 2 . Since the flow of the carriers causes the photo-generated current, the electric potential is different between electrodes 1 and 2. Therefore, the solar cell based on the carbon fiber can be used to power or recharge portable devices. In the proposed carbon fiber-based solar cell, the effects of the thickness and doping concentration in the p- and n-type poly-Si layers on the efficiency of the solar cell were theoretically analyzed by using a finite-difference time-domain (FDTD) algorithm. We assumed that the $\mathrm{p}$ - and n-type poly-Si layers were fabricated by doping silicon with boron (B) and phosphorus (P), respectively. Figure 2(a) shows the short-circuit current density $\left(J_{s c}\right)$ as a function of the thickness of the p-type poly-Si layer $\left(t_{p}\right)$. The absorbed light intensity $\left(I_{a b s}\right)$ with respect to the thickness of the $\mathrm{Si}$ layer $\left(t_{p}\right)$ can be written as follows [13]

$$
I_{a b s}=1-\exp \left(-\alpha_{s} t_{p}\right),
$$

where $\alpha_{s}$ and $t_{p}$ are the absorption coefficient and thickness of the p-type poly-Si layer, respectively. From Eq. (1), it is clearly evident that the absorbed light intensity $\left(I_{a b s}\right)$ is exponentially enhanced by increasing the thickness of the p-type poly-Si layer $\left(t_{p}\right)$. The short-circuit current density $\left(J_{s c}\right)$ can be approximately expressed as follows [14]

$$
\begin{aligned}
& J_{s c}=q \eta_{l h} \eta_{i n j} \eta_{q e} I_{0}, \\
& \eta_{l h}=I_{a b s} / I_{0}
\end{aligned}
$$

where $q$ is the electron charge, $\eta_{l h}, \eta_{i n j}$, and $\eta_{q e}$ are the light harvesting efficiency, charge injection efficiency, and quantum efficiency, respectively, and $I_{0}$ is the input intensity of the illuminating light. In Eq. (2), it is clearly evident that the short-circuit current density $\left(J_{s c}\right)$ is directly proportional to the value of $\eta_{l h}$ [15]. Since the light harvesting efficiency $\left(\eta_{l h}\right)$ is dominantly determined by the absorbed light intensity $\left(I_{a b s}\right)$, the short-circuit current density $\left(J_{s c}\right)$ gradually increases and is finally saturated with increasing thickness of the p-type poly-Si layer $\left(t_{p}\right)$. Figures 2(b) and 2(c) show the open-circuit voltage $\left(V_{o c}\right)$ and fill factor $\left(\Gamma_{f}\right)$, respectively, as a function of the thickness of the p-type poly-Si layer $\left(t_{\mathrm{p}}\right)$. The main parameter to determine the open-circuit voltage $\left(V_{o c}\right)$ is the doping concentration in the p- or n-type poly-Si layer [16]. This means that the open-circuit voltage $\left(V_{o c}\right)$ is not severely affected by the thickness of the p-type poly-Si layer, as shown in Fig. 2(b). The fill factor of the solar cell $\left(\Gamma_{f}\right)$ can be given as shown below [17]

$$
\Gamma_{f}=\frac{J_{\max } V_{\max }}{J_{s c} V_{o c}},
$$




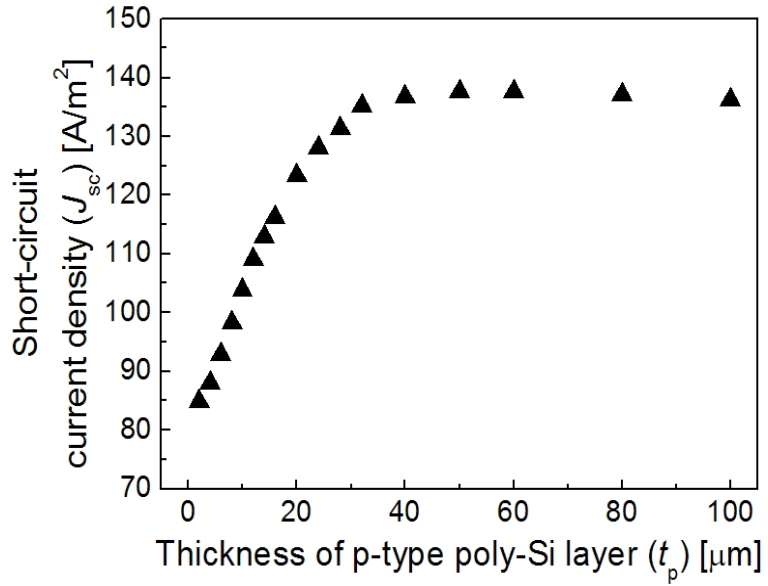

(a)

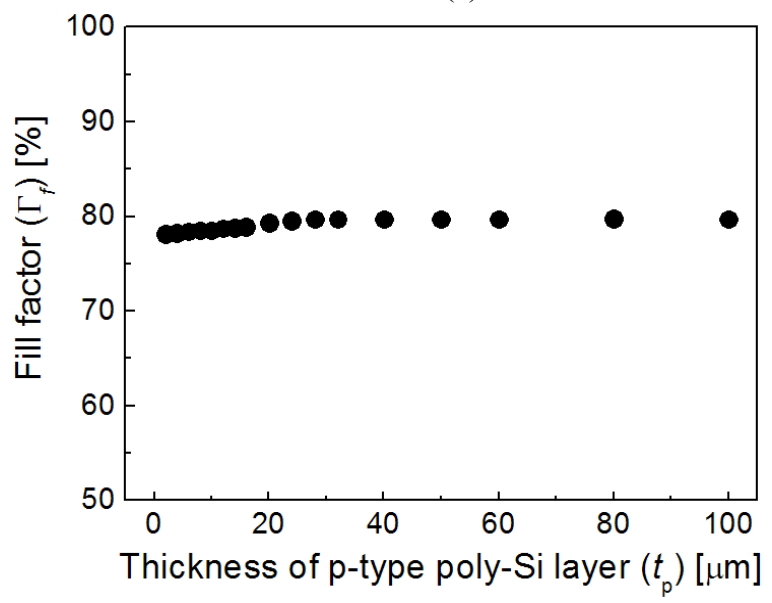

(c)

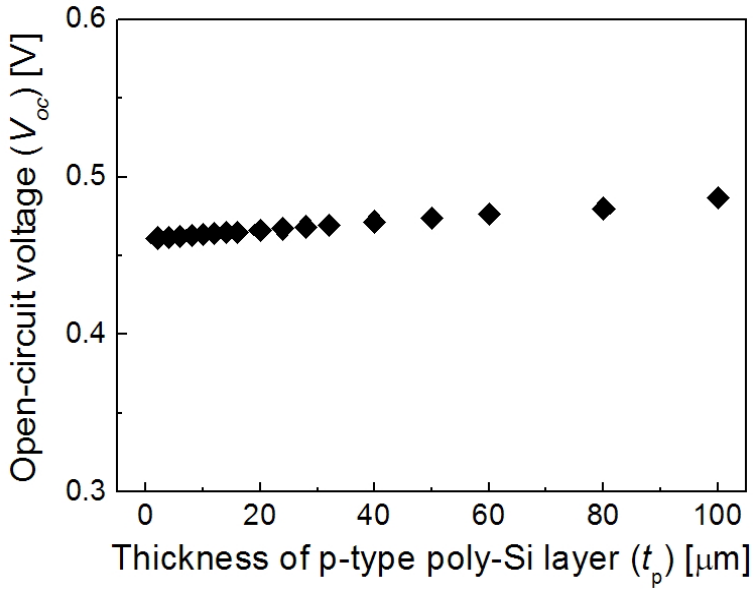

(b)

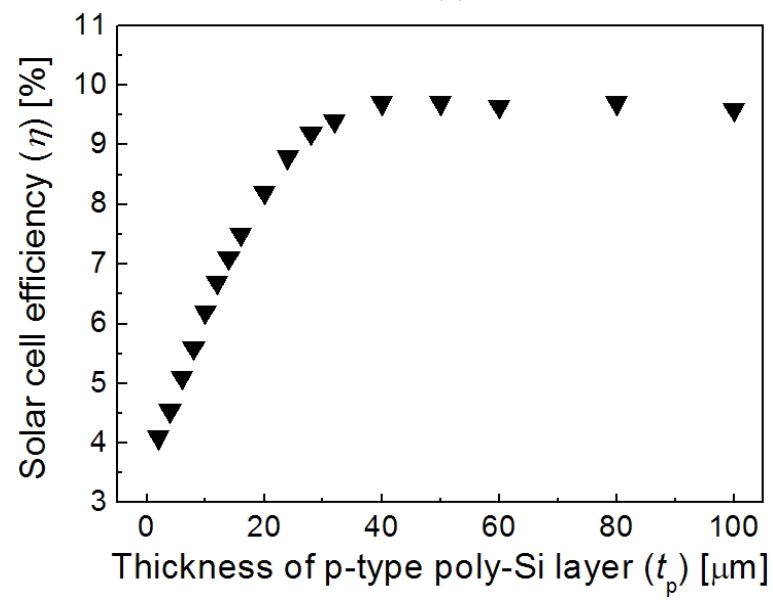

(d)

FIG. 2. The (a) short-circuit current density $\left(J_{s c}\right)$, (b) open-circuit voltage $\left(V_{o c}\right)$, (c) fill factor $\left(\Gamma_{f}\right)$, and (d) solar cell efficiency $(\eta)$ as a function of the thickness of the p-type poly-Si layer $\left(t_{p}\right)$.

where $J_{\max }$ and $V_{\max }$ are the maximum output current density and maximum output voltage of the solar cell, respectively. For the ideal case of the carbon fiber-based solar cell, the fill factor $\left(\Gamma_{f}\right)$ is not significantly affected by the thickness of the p-type poly-Si layer, as shown in Fig. 2(c), because the short-circuit current density $\left(J_{s c}\right)$ and the maximum output current density $\left(J_{\max }\right)$ are simultaneously affected by the thickness of the p-type poly-Si layer. Figure 2(d) shows the variation of the solar cell efficiency $(\eta)$ as a function of the thickness of the p-type poly-Si layer $\left(t_{p}\right)$. The solar cell efficiency $(\eta)$ can be expressed as follows [16]

$$
\eta=\frac{J_{s c} V_{o c} \Gamma_{f}}{P_{i}},
$$

where $P_{i}$ is the intensity of sunlight. Since the solar cell efficiency $(\eta)$ is directly proportional to the short circuit current density $\left(J_{s c}\right)$, the solar cell efficiency $(\eta)$ should gradually increase and finally become saturated by increasing the thickness of the p-type poly-Si layer $\left(t_{p}\right)$.

Figure 3(a) shows the short-circuit current density $\left(J_{s c}\right)$ as a function of the thickness of the n-type poly-Si layer $\left(t_{n}\right)$. The quantum efficiency $\left(\eta_{q e}\right)$ is the ratio of the number of photo-generated electrons collected by the solar cell to the number of photons incident on the solar cell. The quantum efficiency $\left(\eta_{q e}\right)$ is predominantly determined by the collection efficiency of the photo-generated electron. This collection efficiency is affected by the diffusion length of electrons $(L)$ and the thickness of the n-type poly-Si layer $\left(t_{n}\right)$. The quantum efficiency $\left(\eta_{q e}\right)$ with respect to the thickness of the n-type poly-Si layer $\left(t_{n}\right)$ can be approximately expressed as follows [18].

$$
\eta_{q e}=\frac{L}{t_{n}}\left[1-\exp \left(-\frac{t_{n}}{L}\right)\right]
$$

From Eq. (6), it is obvious that the quantum efficiency $\left(\eta_{q e}\right)$ is degraded with increasing thickness of the n-type poly-Si layer $\left(t_{n}\right)$. Since the short-circuit current density $\left(J_{s c}\right)$ is 


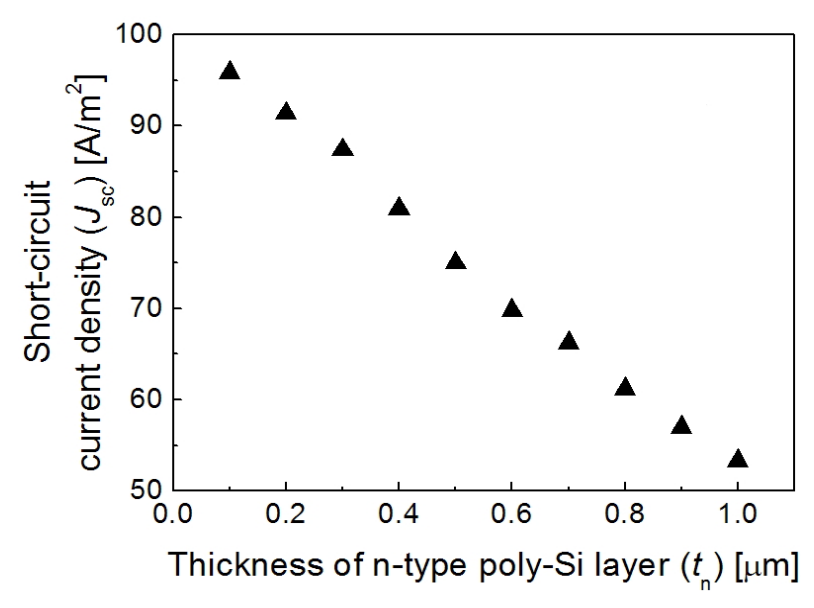

(a)

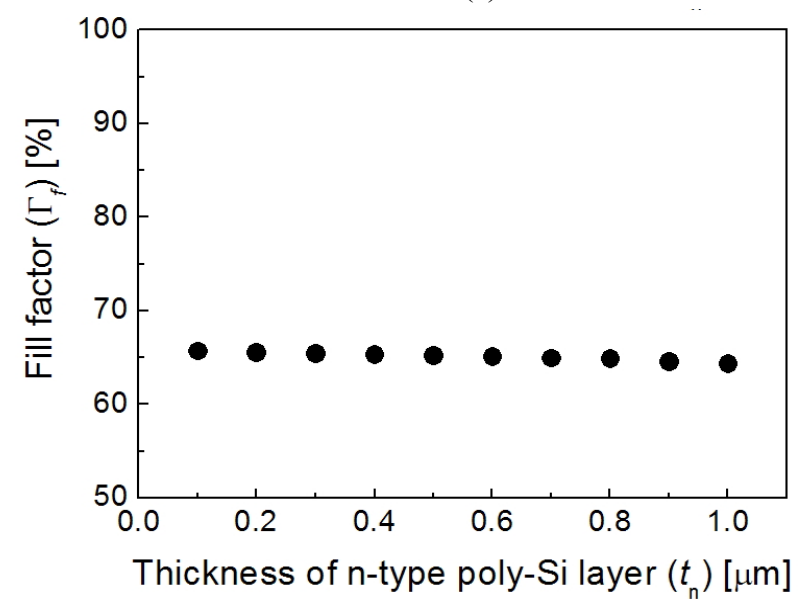

(c)

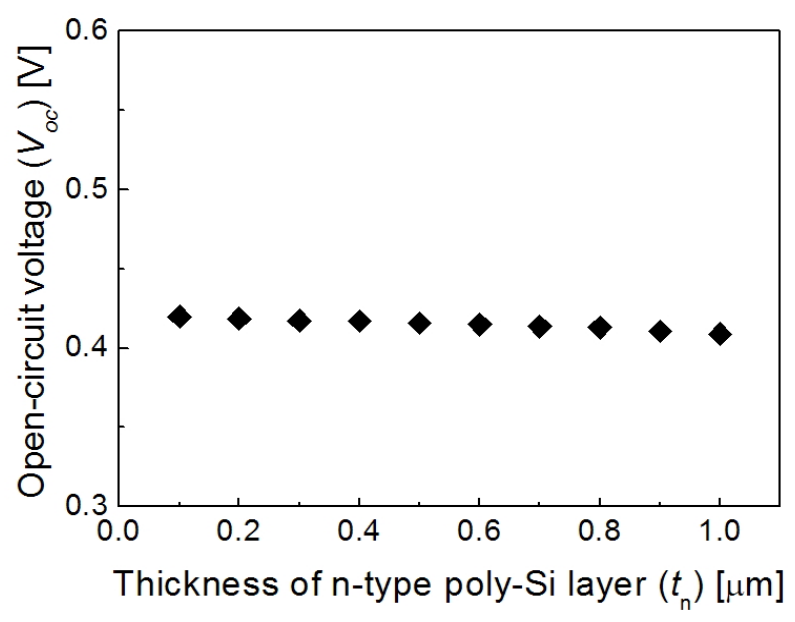

(b)

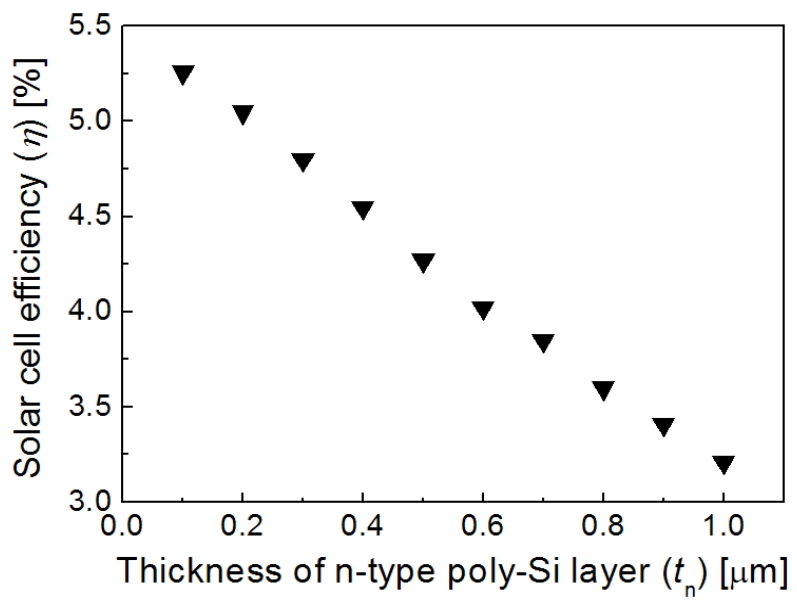

(d)

FIG. 3. The (a) short-circuit current density $\left(J_{s c}\right)$, (b) open-circuit voltage $\left(V_{o c}\right)$, (c) fill factor $\left(\Gamma_{f}\right)$, and $(\mathrm{d})$ solar cell efficiency $(\eta)$ as a function of the thickness of the n-type poly-Si layer $\left(t_{n}\right)$.

directly proportional to the quantum efficiency $\left(\eta_{q e}\right)$ in Eq. (2), the short-circuit current density $\left(J_{s c}\right)$ should be reduced by increasing the thickness of the n-type poly-Si layer $\left(t_{n}\right)$, as shown in Fig. 3(a). Figures 3(b) and 3(c) show the open-circuit voltage and fill factor, respectively, as a function of the thickness of the n-type poly-Si layer. Similar to the case of the p-type poly Si layer, the open-circuit voltage $\left(V_{o c}\right)$ and fill factor $\left(\Gamma_{f}\right)$ are not seriously affected by the thickness of the n-type poly-Si layer. Figure 3(d) shows the solar cell efficiency $(\eta)$ as a function of the thickness of the n-type poly-Si layer $\left(t_{p}\right)$. Since the solar cell efficiency $(\eta)$ is directly proportional to the short-circuit current density $\left(J_{s c}\right)$, the solar cell efficiency $(\eta)$ should be diminished by increasing the thickness of the n-type poly-Si layer $\left(t_{n}\right)$, as observed in Fig. 3(d).

Figure 4(a) shows the variation of the short-circuit current density $\left(J_{s c}\right)$ as the doping concentration in the p-type poly-Si layer $\left(N_{p}\right)$ increases. The increase of the doping concentration in the p-type poly-Si layer $\left(N_{p}\right)$ substantially produces holes in the poly-Si layer. The absorption coefficient of the poly-Si layer strongly depends on the doping concentration in the poly-Si layer $\left(N_{p}\right)$ because the holes in the p-type poly-Si layer absorb photons. The absorption coefficient of the p-type poly-Si layer $\left(\alpha_{s}\right)$ can be written as shown below [19]

$$
\begin{aligned}
& \alpha_{s}=\frac{\alpha_{e h}}{\alpha_{e h}+\alpha_{f c}}, \\
& \alpha_{f c}=2.7 \times 10^{-24} N_{p} \lambda^{2}+2.6 \times 10^{-27} N_{n} \lambda^{3}
\end{aligned}
$$

where $\alpha_{e h}$ is an intrinsic absorption coefficient of $\mathrm{Si}, \alpha_{g_{c}}$ is the absorption coefficient of a free electron, and $N_{p}$ and $N_{n}$ are the doping concentrations in the p-type and n-type poly-Si layers, respectively. Substituting Eq. (8) into Eq. (1) yields the absorbed light intensity $\left(I_{a b s}\right)$ as follows.

$$
I_{a b s}=1-\exp \left(-\frac{\alpha_{e h}}{\alpha_{e h}+2.7 \times 10^{-24} N_{p} \lambda^{2}+2.6 \times 10^{-27} N_{n} \lambda^{3}} d\right)
$$


It is obvious that the effects of the doping concentration in the n-type poly-Si layer $\left(N_{n}\right)$ on the absorption coefficient and absorbed light intensity are negligible because of its small contribution. From Eq. (9), it is clearly evident that the absorbed light intensity $\left(I_{a b s}\right)$ should be reduced by increasing the doping concentration in the p-type poly-Si layers $\left(N_{p}\right)$. Therefore, the short-circuit current density $\left(J_{s c}\right)$ is monotonously decreased by increasing the doping concentration in the p-type poly-Si layer $\left(N_{p}\right)$, as shown in Fig. 4(a).

Figure 4(b) shows the open-circuit voltage $\left(V_{o c}\right)$ as the doping concentration in the n-type poly-Si layer $\left(N_{n}\right)$ increases. The doping concentration in the p-type poly-Si layer is closely related to the open-circuit voltage of the solar cell, which is a measure of the amount of recombination loss in the solar cell. Increasing the doping concentration in the p-type poly-Si layer reduces the electron concentration in the p-type poly-Si layer, resulting in suppression of the electron-hole-recombination. The open-circuit voltage $\left(V_{o c}\right)$ with respect to the doping concentration in the p-type
poly-Si layer can be written as follows [20]

$$
V_{o c}=\frac{k T}{q} \ln \left[\Delta N_{n}\left(N_{p}+\Delta N_{p}\right) / n_{i}^{2}+1\right]
$$

where $\mathrm{k}$ is the Boltzmann's constant. $T$ is the absolute temperature, $n_{i}$ is the intrinsic carrier concentration, and $\Delta n$ and $\Delta p$ are the photo-generated excess electron and hole densities, respectively. From Eq. (10), it is clearly evident that increasing the doping concentration in the p-type poly-Si layer $\left(N_{n}\right)$ slightly improves the open-circuit voltage $\left(V_{o c}\right)$, as shown in Fig. 4(b).

Figure 4(c) shows the fill factor $\left(\Gamma_{f}\right)$ as a function of the doping concentration in the p-type poly-Si layer. The fill factor $\left(\Gamma_{f}\right)$ is not critically affected by the doping concentration in the p-type poly-Si layer $\left(N_{\mathrm{p}}\right)$ because the opencircuit voltage $\left(V_{o c}\right)$ and maximum output voltage $\left(V_{\max }\right)$ are simultaneously affected by the doping concentration in

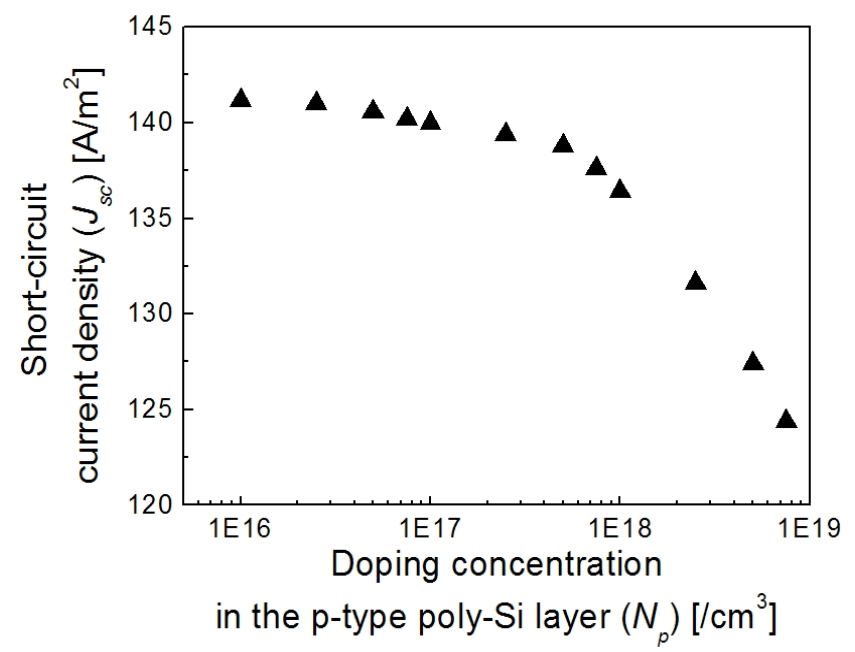

(a)

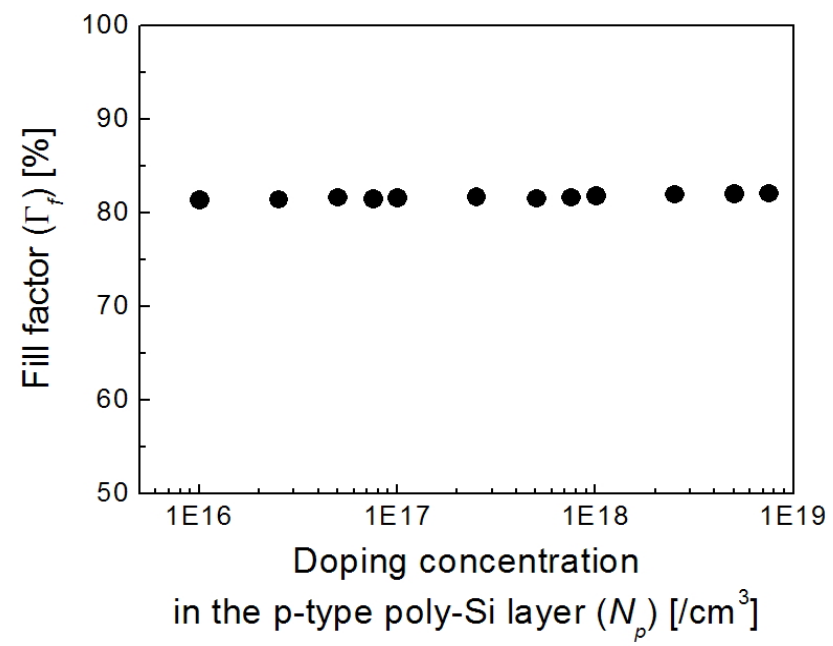

(c)

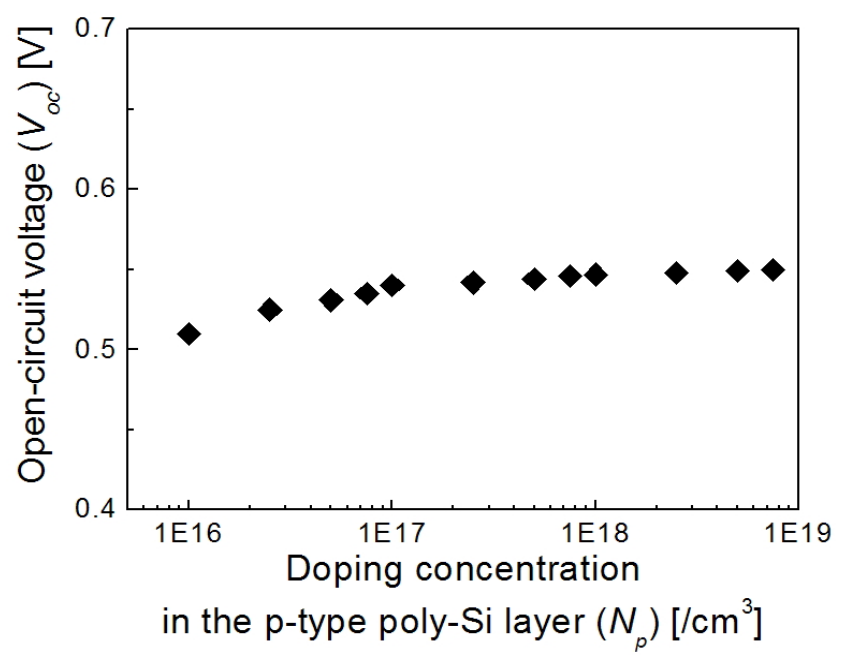

(b)

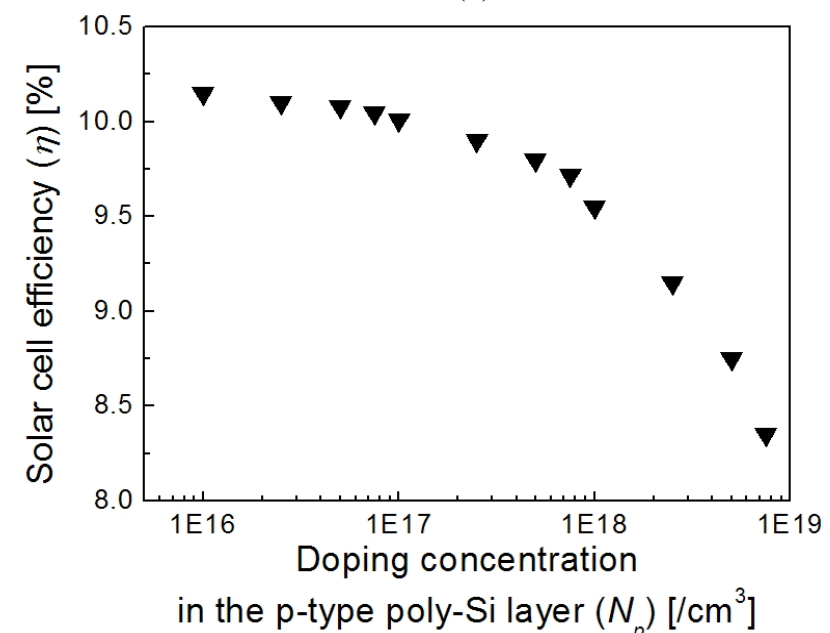

(d)

FIG. 4. The (a) short-circuit current density $\left(J_{s c}\right)$, (b) open-circuit voltage $\left(V_{o c}\right)$, (c) fill factor $\left(\Gamma_{f}\right)$, and $(\mathrm{d})$ solar cell efficiency $(\eta)$ as a function of the doping concentration in the p-type poly-Si layer $\left(N_{p}\right)$. 
the p-type poly-Si layer $\left(N_{\mathrm{p}}\right)$. Figure $4(\mathrm{~d})$ shows the variation of the solar cell efficiency $(\eta)$ as a function of the doping concentration in the p-type poly-Si layer $\left(N_{p}\right)$. The solar cell efficiency $(\eta)$ is gradually decreased by the doping concentration in the p-type poly-Si layer $\left(N_{p}\right)$ because the variation of the short-circuit current density $\left(J_{s c}\right)$ is much higher than that of the open-circuit voltage $\left(V_{\text {oc }}\right)$, as shown in Figs. 4(a) and 4(b).

Figure 5(a) shows the short-circuit current density $\left(J_{s c}\right)$ as a function of the doping concentration in the n-type poly-Si layer $\left(N_{n}\right)$. From Eq. (9), it is clearly evident that the absorbed light intensity $\left(I_{a b s}\right)$ should be reduced by increasing the doping concentration in the n-type poly-Si layer $\left(N_{n}\right)$. Therefore, the short-circuit current density $\left(J_{s c}\right)$ is slightly reduced by increasing the doping concentration in the n-type poly-Si layer $\left(N_{n}\right)$. Figure 5(b) shows the variation of the open-circuit voltage $\left(V_{o c}\right)$ as the doping concentration in the n-type poly-Si layer $\left(N_{n}\right)$ increases.
Increasing the doping concentration in the n-type poly-Si layer reduces the hole concentration in the n-type poly-Si layer, resulting in suppression of the electron-hole-recombination. The open-circuit voltage $\left(V_{o c}\right)$ with respect to the doping concentration in the n-type poly-Si layer can be written as follows [20].

$$
V_{o c}=\frac{k T}{q} \ln \left[\Delta N_{p}\left(N_{n}+\Delta N_{n}\right) / n_{i}^{2}+1\right]
$$

From Eq. (11), it is clearly evident that increasing the doping concentration in the n-type poly-Si layer $\left(N_{n}\right)$ enhances the open-circuit voltage $\left(V_{o c}\right)$, as shown in Fig. 5(a). Figure 5(c) shows the fill factor $\left(\Gamma_{f}\right)$ as a function of the doping concentration in the n-type poly-Si layer $\left(N_{n}\right)$. Similar to the case of the n-type poly-Si layer, the fill factor $\left(\Gamma_{f}\right)$ is not significantly affected by the doping

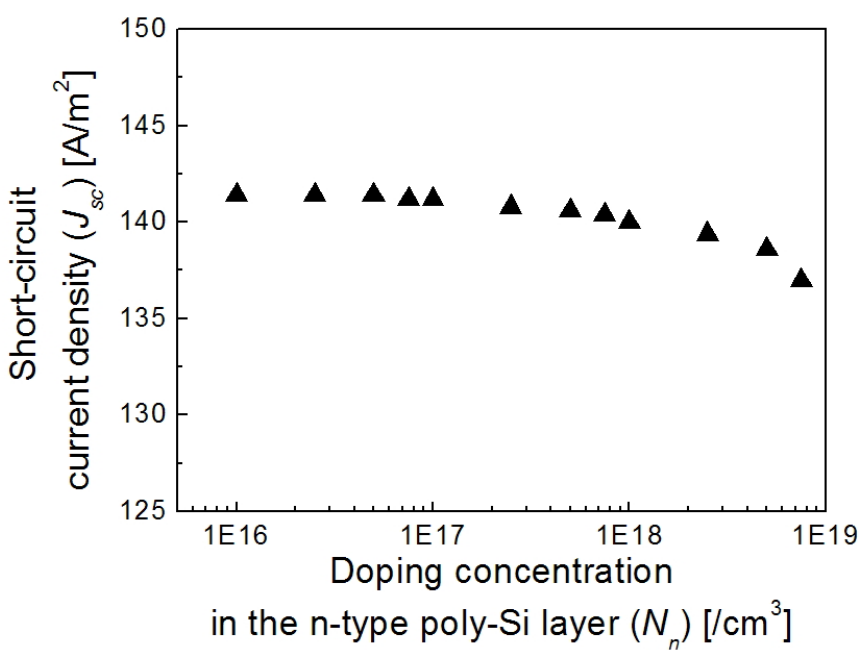

(a)

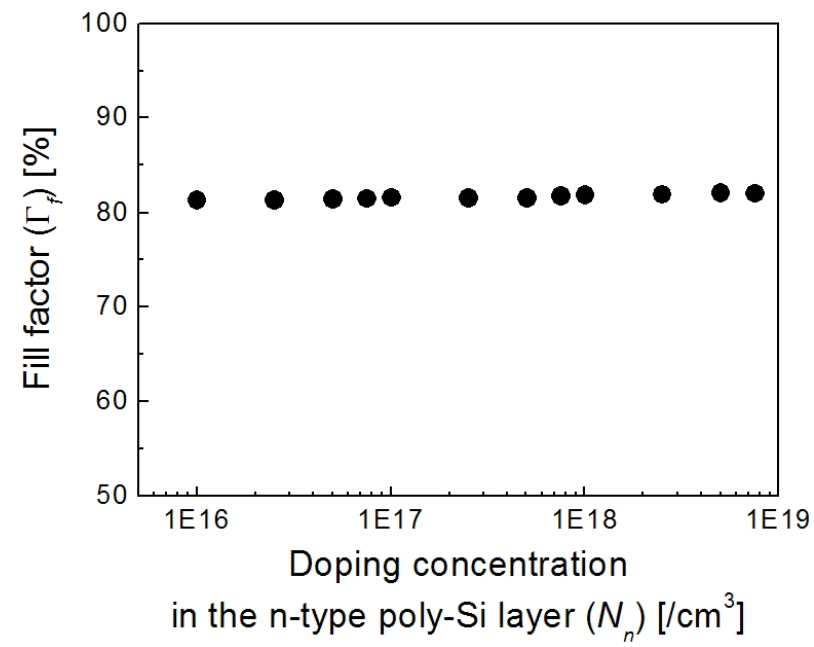

(c)

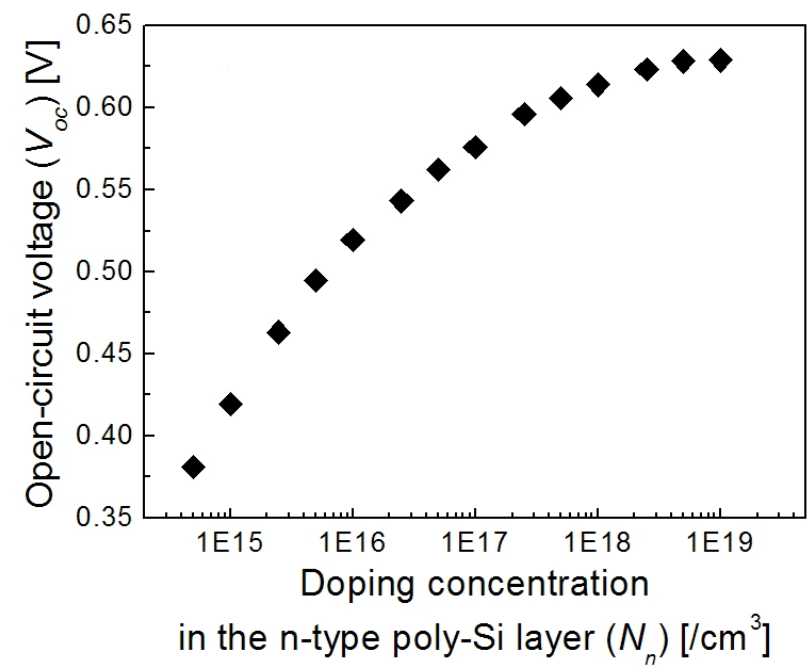

(b)

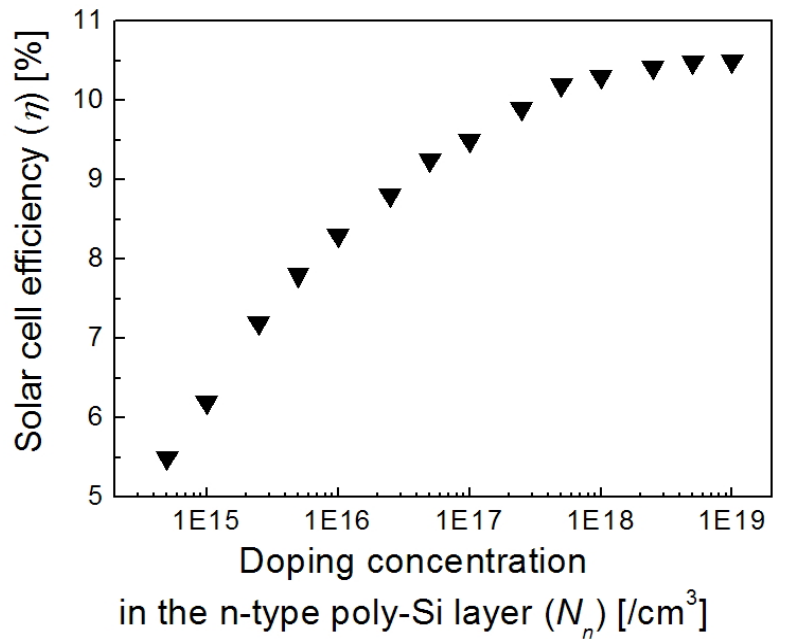

(d)

FIG. 5. The (a) short-circuit current density $\left(J_{s c}\right)$, (b) open-circuit voltage $\left(V_{o c}\right)$, (c) fill factor $\left(\Gamma_{f}\right)$, and $(\mathrm{d})$ solar cell efficiency $(\eta)$ as a function of the doping concentration in the n-type poly-Si layer $\left(N_{n}\right)$. 
concentration in the n-type poly-Si layer $\left(N_{\mathrm{n}}\right)$. Figure $5(\mathrm{~d})$ shows the solar cell efficiency $(\eta)$ as a function of the doping concentration in the n-type poly-Si layer $\left(N_{n}\right)$. The solar cell efficiency $(\eta)$ is gradually increased by the doping concentration in the n-type poly-Si layer $\left(N_{n}\right)$ because the variation of the short circuit current density $\left(J_{s c}\right)$ is much smaller than that of the open-circuit voltage $\left(V_{\mathrm{oc}}\right)$, as observed in Figs. 5(a) and 5(b).

\section{CONCLUSION}

We analyzed the efficiency of the solar cell based on a carbon fiber as functions of the thickness and doping concentration in the $\mathrm{p}$ - and n-type poly-Si layers. We found that the solar cell efficiency $(\eta)$ is directly proportional to the short circuit current density $\left(J_{s c}\right)$. The short-circuit current density $\left(J_{s c}\right)$ gradually increased and finally became saturated by increasing the thickness of the p-type poly-Si layer $\left(t_{p}\right)$ because of the dependence of the light harvesting efficiency $\left(\eta_{l h}\right)$ on the absorbed light intensity $\left(I_{a b s}\right)$. Therefore, the solar cell efficiency $(\eta)$ should gradually increase and finally become saturated by increasing the thickness of the p-type poly-Si layer $\left(t_{p}\right)$. However, the solar cell efficiency $(\eta)$ should decrease with increasing the thickness of the n-type poly-Si layer $\left(t_{n}\right)$ because of the degradation of the quantum efficiency $\left(\eta_{q e}\right)$ which is closely related to the short-circuit current density $\left(J_{s c}\right)$. Since the doping concentration in the p-type poly-Si laser $\left(N_{p}\right)$ is mainly attributed to the variation of the absorption coefficient of free electrons $\left(\alpha_{f c}\right)$ rather than that in the n-type poly-Si layer $\left(N_{n}\right)$, the solar cell efficiency $(\eta)$ is adequately elevated by reducing the doping concentration in the p-type poly-Si layer $\left(N_{p}\right)$. The dependence of the open-circuit voltage $\left(V_{o c}\right)$ on the doping concentration in the n-type poly-Si layer $\left(N_{n}\right)$ should improve the solar cell efficiency $(\eta)$ while increasing the doping concentration in the n-type poly-Si layer $\left(N_{n}\right)$. An improvement of the solar cell efficiency based on the carbon fiber to $\sim 10.5 \%$ was achieved when the physical parameters of the p- and n-type poly-Si layers in the carbon fiber-based solar cell were $t_{p}=40 \mu \mathrm{m}, t_{n}=0.1$ $\mu \mathrm{m}, N_{p}=1 \times 10^{16} \mathrm{~cm}^{-3}$, and $N_{n}=1 \times 10^{19} \mathrm{~cm}^{-3}$.

\section{REFERENCES}

1. J. B. Lee, Z. Z. Chen, M. G. Allen, A. Rohatgi, and R. Arya, "A miniaturized high-voltage solar cell array as an electrostatic MEMS power supply,” J. Microelectromech Syst. 4, 102-108 (1995).

2. B. Z. Tian, T. J. Kempa, and C. M. Liber, "Single nanowire photovoltaics," Chem. Soc. Rev. 38, 16-24 (2009).

3. J. Kim, S. Nam, J. Jeong, H. Kim, and Y. Kim, "Effect of silicon-nanoparticle addition on the nanostructure of polythiophene: Fullurene bulk heterojunction solar cells," J.
Korean Phys. Soc. 61, 234-238 (2012).

4. S. H. Mohamed, "Transparent conductive gallium-doped indium oxide nanowires for optoelectronic applications," J. Korean Phys. Soc. 62, 902-905 (2013).

5. Y. Duan, H. Yang, P. Jiang, and P. Wang, "Research on the solar concentrating optical system for solar energy utilization," J. Opt. Soc. Korea 17, 371-375 (2013).

6. Z. Y. Fan, H. Razavi, J. W. Do, A. Moriwaki, O. Ergen, Y. L. Chueh, P. W. Leu, J. C. Ho, T. Takahashi, L. A. Reichertz, S. Neale, K. Yu, M. Wu, J. W. Ager, and A. Javey, "Three-dimensional nanopillar-array photovoltaics on low-cost and flexible substrates," Nature Materials 8, 648-653 (2009).

7. M. Toivola, M. Ferenets, P. Lund, and A. Harlin, "Photovoltaic fiber," Thin Solid Films 517, 2799-2802 (2009).

8. B. O. Connor, K. P. Pipe, and M. Shtein, "Fiber based organic photovoltaic devices," Appl. Phys. Lett. 92, 1933061-1933063 (2008).

9. W. Xu, S. Choi, and M. G. Allen, "Hairlike carbon-fiberbased solar cell," Micro Electro Mechanical Systems, IEEE International Conference, 1187-1190 (2010).

10. X. Zhang and Z. Shen, "Carbon fiber paper for fuel cell electrode," Fuel 81, 2199-2202 (2002).

11. J. Yun, J. Kim, H. S. Kojori, S. J. Kim, C. Tong, and W. A. Anderson, "Current enhancement of aluminum doped $\mathrm{ZnO} / \mathrm{n}-\mathrm{Si}$ isotype heterojunction solar cells by embedding silver nanoparticles," J. Nanosci. Nanotechol. 13, 5547-5551 (2013).

12. D. N. Weiss, H. C. Yuan, B. G. Lee, H. M. Branz, S. T. Meyers, A. Grenville, and D. A. Keszler, "Nanoimprinting for diffractive light trapping in solar cells," J. Vac. Sci. Technol. B 28, C6M98-C6M103 (2010).

13. M. Dimitrov, K. Kochev, and D. Pavlov, "The effect of thickness and stoichiometry of the $\mathrm{PbO}$ layer upon the photoelectric properties of the $\mathrm{Pb} / \mathrm{PbO} / \mathrm{PbSO} / \mathrm{H}_{2} \mathrm{SO}_{4}$ electrode," J. Electroanal. Chem. 183, 145-153 (1985).

14. K. Zhu, N. R. Neale, A. Miedaner, and A. J. Frank, "Enhanced charge-collection efficiencies and light scattering in dye-sensitized solar cells using oriented $\mathrm{TiO}_{2}$ nanotubes arrays," Nano Lett. 7, 69-74 (2007).

15. D. Gentilini, D. D'Ercole, A. Gagliardi, A. Brunetti, A. Reale, T. Brown, and A. Di Carlo, "Analysis and simulation of incident photon to current efficiency in dye sensitized solar cells," Superlattice Microst. 47, 192-196 (2010).

16. Y. Chiba, A. Islam, Y. Watanabe, R. Komiya, N. Koide, and L. Han, "Dye-sensitized solar cells with conversion efficiency of 11.1\%," Jpn. J. Appl. Phys. 45, L638-L640 (2006).

17. B. Qi and J. Wang, "Fill factor in organic solar cells," Phys. Chem. Chem. Phys. 15, 8972-8982 (2013).

18. G. L. Araujo, A. Cuevas, and J. M. Ruiz, "The effect of distributed series resistance on the dark and illuminated current-Voltage characteristics of solar cells," IEEE Trans. Electron Devices 33, 391-401 (1986).

19. D. A. Clugston and P. A. Basore, "Modelling free-carrier absorption in solar cells," Prog. Photovoltaics 5, 229-236 (1997).

20. R. A. Sinton and A. Cuevas, "Contactless determination of current-voltage characteristics and minoritycarrier lifetimes in semiconductors from quasi-steady-state photoconductance data," Appl. Phys. Lett. 69, 2510-2512 (1996). 